\title{
Prevention Of Drug And Substance Abuse In Secondary Schools: A Case Of Garissa County, Kenya
}

\author{
Joseph Kisaka \\ Department of Educational Foundations \& Policy Studies \\ School of Education, Pwani University, Kenya.
}

\begin{abstract}
This paper investigated the prevention of drug and substance abuse in secondary schools in Garissa County of North Eastern Province, Kenya. The research problem emanated from the concern that drug abuse has remained a serious habit in Kenyan schools despite efforts by various stakeholders such as the government, parents, teachers, and religious leaders to reduce it. While this habit continues to cause mayhem among students in secondary schools, studies on its preventive measures particularly in Garissa County remain sunk. Therefore, the study upon which this paper is developed was focused on finding out the existence of drug advisors against drug and substance abuse, examining actions taken by the school administration towards students who abuse drugs, and establishing ways of minimizing drug and substance abuse among students in Garissa County. All the available schools were included in the study sample which comprised of all the 13 head teachers, all the 104 teachers, and 780 students. The information was elicited by use of questionnaires, interviews and focused group discussions. Quantitative data was analyzed through descriptive statistics while qualitative data was presented according to themes. The findings showed that the advisors against drug and substance abuse included religious leaders, parents, teachers as well as guidance and counseling masters. Students were advised during sessions like prayer, opening and closing, assembly, guidance and counseling sessions as well as during the course of administering punishments to students. The existing measures taken in case a student was found abusing drugs and substances of abuse included seeking explanation from parents, administering corporal punishment, suspension from school, as well as taking student to the guidance and counselling master or teacher. Therefore, urgent measures should be put in place in order to save the students from the dangers of drug abuse. Therefore the study came up with measures to curb the vice that included creating awareness in the schools through campaigns against the vice of drug and substance abuse as well as strengthening the department of guidance and counselling in schools and the school administration being more strict in enforcing school rules and regulations. Otherwise students are likely to lose track of their educational careers if such measures are not put in place.
\end{abstract}

Key words: Drug, Drug and substance abuse, Guidance and counseling, School awareness campaigns.

\section{INTRODUCTION}

Drug abuse is a serious public health problem which has become an area of concern in the Kenyan society, specifically in schools. Persons, who abuse drugs such as alcohol, marijuana, tobacco, and miraa, suffer from drug addiction and other psychotic problems like hallucinations. It raises questions on why such drug abusers fail to avoid the abuse of drugs on the account of its health implications. In the United States of America, drug addiction is still a serious problem affecting young people even in schools. In this country, the school system generally combines two (2) approaches as preventive measures against drug abuse. The first approach emphasizing on zero- tolerance which mandates the suspension or expulsion of any student caught smoking, drinking, or using illegal drugs (CASA, 2017). Another preventive 
measure is through the curriculum which plays an important role to educate students about the risk of substance abuse. In the curriculum, students are taught, for instance, refusal skills against drugs. Students are also taught cognitive skills to resist external pressures like advertisements, peer pressure and poor choices of role models, which lure students into drug abuse (CASA, 2017).

There are also organizational bodies which have been involved in drug abuse prevention in America. These include the National Institute of Drug Abuse (NIDA) which sponsors clubs/movements in schools dabbed 'Just Say No' by offering such clubs with awareness materials like booklets and T- shirts. Such materials carry messages against drug abuse hence members find it to reasonably shun drug abuse (NIDA, 2015).

In a similar way, the youth in schools in the United Kingdom are also battling with the problem of drug and substance abuse. There are various organizational bodies in the United Kingdom interested in combating or preventing drug and substance abuse in schools. First, there are the Local Education Authorities which are responsible for determining school syllabuses. Through such syllabuses, drug education can be taught in schools. Furthermore, there is the Department of Education and Sciences whose functions include giving advice on health education in schools for children up to 16 years of age. The school council is another body which is responsible for the development and promotion of schools council health education projects in schools for age ranges of 5-8, 9 - 13 year olds, and 13-18 year olds. Furthermore, there is the Teachers Advisory Council on Alcohol and Drug Education (TECADE), a voluntary agency, whose activities include conducting in-service training courses for teachers, and producing publications on drug-related information (Milliken, 2017).

Even by 1979, the Kenyan authorities were still of the opinion that drug use among Kenyan youths in and outside school had not yet reached an extent which could justify an alarm (Nyambe, 1979). In fact, by that time, there was no drug education in the school curriculum. However, the generally accepted view by Kenyan authorities at that time was that some drug education on dangerous drugs could be included in adult education programmes. For instance, headmasters, through the Department of Guidance and Counselling of the Ministry of Education, were supposed to receive lessons on kinds of dangerous drugs (Nyambe, 1979). There was a strong feeling by Kenyan authorities that the drug problem could be best dealt with by parents. Startling enough, the research carried out by Nyambe (1979) reveals that drugs like alcohol, cannabis, valium and miraa were used and abused by students as well as non- students.

The type of preventive measures which were emphasized by 1979 , were those directed towards limiting the availability of drugs which is one of the causes of drug abuse among students and non-students alike. One of these measures was that clinics were being established in high schools, colleges and universities to help furnish the Ministry of Education with records of drug addiction so that remedial steps could be taken (Nyambe, 1979).

The government established a national agency called NACADA (National Agency for the Campaign Against Drug Abuse) on 26th March 2001, and was declared a parastatal in 2007. NACADA is mandated to facilitate setting up of rehabilitation centres and to target the youth both within the school environment and outside as concerns prevention, reduction, and control of drug and substance abuse. This agency (NACADA) has held many open forums and workshops to sensitize young people both in school and outside on the dangers of drug abuse (Kiiru, 2004; Kombo, 2005). 
In the school community, there were been harsh disciplinary measures taken against drug abusers. This resulted to expulsions or suspensions in most of the Kenyan public schools (City Education Department, 1979; Kombo, 2005). Suspension of the students has a consequence of reduced interest in studies among students which is eventually an economic loss to parents and guardians who pay fees. After the suspension period is over, the parent is expected to act as a counsellor to his or her child so that he or she does not repeat the habit of drug abuse in the school once readmitted. In case a student is expelled; he or she would look for another school which would mean transferring the problem of drug abuse from one school to another in case they are admitted to new schools.

There have also been the guidance and counselling departments in schools to assist students in general and drug abusers in particular to avoid the vice. The government, through the Teachers Service Commission (TSC) has employed heads of these departments. Their responsibility is to be in charge of counselling students in matters like shunning drug abuse. The head of department can also invite guest speakers, Parents Teachers Association (PTA) members, religious leaders, medics and old students to assist them in advising students on the dangers of drug abuse (City Education Department, 1979; Kombo, 2005). Furthermore, the head of this department has a role to make arrangements with teachers within the same school who are conversant with students in their classes, or any other qualified teacher to advise the students against drug abuse.

\section{Statement of the Problem}

Drug abuse is a serious and recent phenomenon in Kenya in general and schools in particular. Various efforts have been done by the stakeholders to minimize drug abuse in schools, but the problem has still persisted. The government through the Teachers Service Commission (TSC) has employed many teachers as HoDs of Guidance and Counselling to offer valuable advice to students against drug abuse. Various stakeholders have also organized workshops for students, and even parents and religious leaders have counselled students on how to live drugfree lives. However, with all these efforts, drug abuse has persisted and remained a serious problem in Kenyan schools. The infiltration of drugs into Kenyan schools has raised a lot of concern among all the stakeholders. The study therefore, intended to look at the preventive measures of drug and substance abuse in Garissa County where no such study has been carried out before. The study sought to fulfill the following objectives:

1. To find out the preventive measures existing in secondary schools against the habit of drug and substance abuse in Garissa County.

2. To identify the best ways that could be employed to curb drug and substance abuse in secondary schools in Garissa County.

\section{METHODOLOGY}

A survey was conducted to examine the preventive measures against drug and substance abuse in Garissa County in Kenya. The target population was 4,734 comprising of Head teachers, teachers and students from which a sample size of 13 head teachers, 104 teachers, and 780 students was obtained. In this case all the available schools were included in the sample as well as all the head teachers. Eight longest serving teachers were selected from every school making a total of 104. Students were first stratified into their classes before the use of systematic random sampling to pick students using the class registers, and thus a sample size of seven hundred eighty (780) students was arrived at. The information was elicited by use of questionnaires, interviews and focused group discussions. Quantitative data was analyzed through descriptive statistics. Data was presented in the form of percentages on bar graphs, pie charts, and tables. Qualitative data on the other hand was analyzed and presented thematically. 


\section{FINDINGS AND DISCUSSION}

The collected data was analyzed based on the data collection instruments used, findings of which are presented as indicated in this section.

\section{Preventive Measures in Existence School rules and regulations}

In Garissa County, school rules and regulations were clearly spelt out. The study established that children were introduced to these rules and regulations at the time of admission into secondary schools. Observation of these school rules and regulations was further reinforced during religious gatherings. Students were told of the importance of observing and obeying rules and regulations by religious leaders like Shiekhs and Imams. It was a practice during opening and closing ceremonies to remind students of the importance of obeying the school rules and regulations. The young Muslim Society of North Eastern Province, whose headquarters are in Garissa town, was reported to also have been making student follow-ups in schools to make sure they maintain moral uprightness and obedience through the school rules and regulations. The value of obeying the laid down school rules and regulations was cited by $53.8 \%$ of the students as bringing discipline in the schools while $78.2 \%$ of the student said it would bring about good academic performance. However, $82.9 \%$ of the students responded that disobeying the school rules and regulations would result in poor academic performance. A rating of the existence of the school rules and regulations, in terms of whether they were very many, many, few or very few was conducted and reported the results reflected in Figure 1.

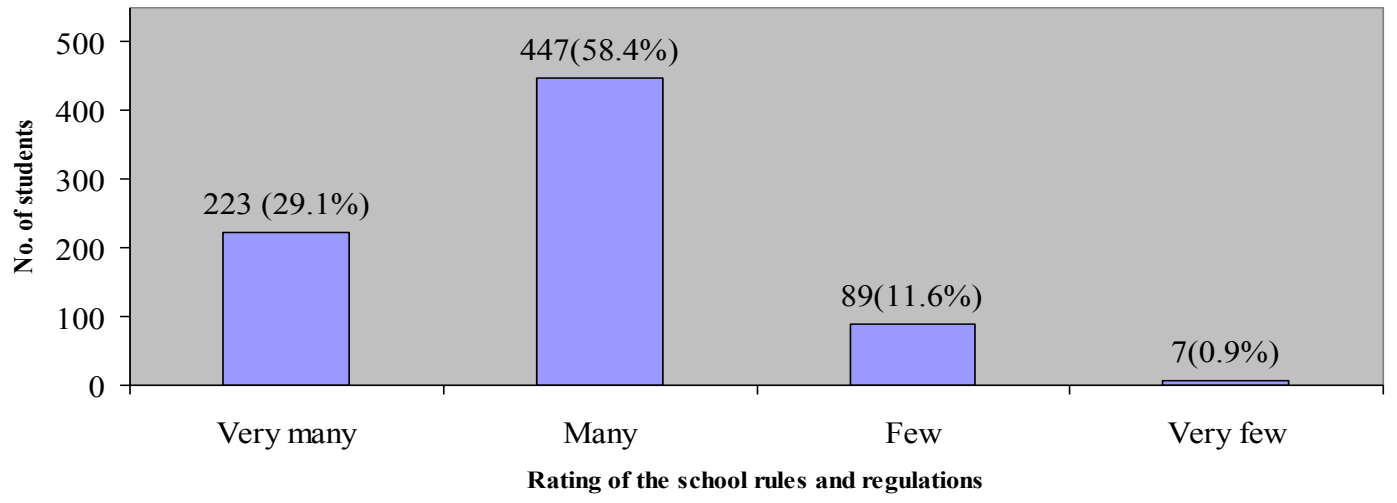

Figure 1: Student ratings of the existence of school rules and regulations

Figure 1 shows students' ratings of school rules and regulations where $223(29.1 \%)$ reported that they were very many, 447 (58.4\%) reported that they were many, $89(11.6 \%)$ reported that they were few while $7(0.9 \%)$ reported that they were very few rules and regulations in their schools. This implies that most students had the view that there were many school rules and regulations to be observed. This view of students can be interpreted to mean that some students broke the school rules and regulations because they thought they were either many or very many.

The study further established that the school rules and regulations had prohibited certain substances from the school compound and also from being possessed by students. In Garissa County, such prohibited substances from the schools included narcotic drugs like miraa, alcohol, bhang, cocaine, and cigarettes. Other prohibited substances included harmful weapons, non-school uniform, foodstuffs from home, mobile phones, and ornaments like jewellery (bangles and necklace). 


\section{Drug advisors against drug abuse}

Furthermore, students were asked whether they have been advised about the dangers of taking drugs and $98.6 \%$ of the students reported that they had been advised while $1.4 \%$ students reported that they were not advised on drugs. Figure 2 illustrates students' responses on individuals who advise them against the habit of drug abuse.

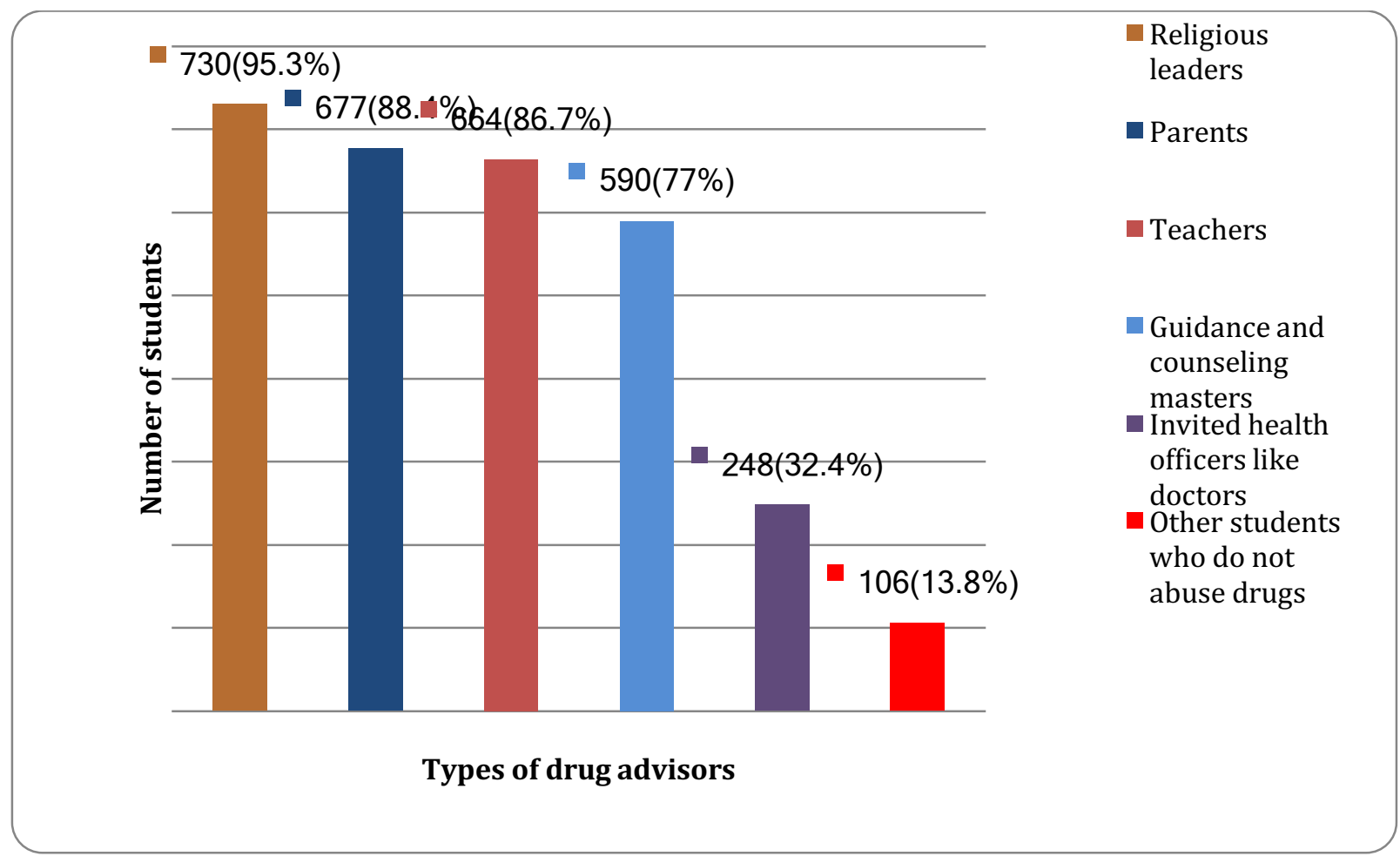

Figure 2: Drug abuse advisors for students in schools

Figure 2 illustrates questionnaire responses from students. It shows that among the students who were advised on drugs, $95.3 \%$ students reported that they were advised by religious leaders, $88.4 \%$ by their parents, $86.7 \%$ )by their teachers while $77.0 \%$ reported that they were advised by guidance and counselling teachers in the school. The study therefore revealed that the chief advisors on abuse of drugs were religious leaders. In this case, they were the Shiekhs and Imams since majority of the students were Muslims. These religious leaders visited the schools frequently. Furthermore, students were also allowed to go out of school during Friday prayers to worship in Mosques of their own choice. In those religious places, they would be advised by religious leaders against vices like drug abuse.

Similarly, parents were also identified as major advisors by $88.4 \%$ of the students. This is because parents expect success of their children and were aware that drug abuse would make their children immoral and therefore, interfere negatively with their success in academics and life as a whole. Furthermore, teachers were also identified as main advisors as denoted by 86.7 $\%$. This could be because they handle those drugs-related cases and therefore, were bound to advice students involved in drug abuse against the vice.

Teachers were also asked to give their views about when students were advised against the vice of abusing drugs. The following were their responses: 
Table 1: Teachers' Responses on when Students were advised against drug abuse

\begin{tabular}{lll}
\hline When students are advised against drug abuse & $\begin{array}{l}\text { Number of by } \\
\text { teachers }\end{array}$ & per cent \\
\hline Opening and closing sessions & 77 & 74.0 \\
$\begin{array}{l}\text { During assembly sessions } \\
\text { Guidance and counseling sessions }\end{array}$ & 21 & 20.2 \\
$\begin{array}{l}\text { During the course of administering } \\
\text { punishments to the students }\end{array}$ & 91 & 87.5 \\
During prayer or religious meetings & 19 & 18.3 \\
During classroom sessions & 98 & 94.2 \\
Very rarely & 33 & 31.7 \\
\hline
\end{tabular}

Source: Field Data, 2017

The study revealed that students were advised against the vice of drug abuse on main occasions like during prayer meetings (94.2\%), guidance and counselling sessions (87.5\%), opening and closing sessions (74\%) and during assembly sessions (59.5\%). Other occasions were during religious meetings or gatherings (94.2\%). This finding was also supported by the head teachers during interviews. In Garissa County, there was always existence of religious clubs, namely; the Islamic Society club which was well-funded by religious organizations outside the school and even by the school administration. Furthermore, guidance and counselling sessions were sometimes organized to advise students against the vice of drug abuse. This response was supported by teachers (87.5\%) as well as head teachers. In the schools, the guidance and counselling department is tasked by the Teachers' Service Commission to advise learners on various issues including avoiding drug abuse. Another response where teachers and head teachers agreed as the time they advised students against the vice was during opening and closing sessions (74.0\%).

Head teachers also added that students were advised during prep time while teachers never provided it as a response about the time students were advised. Head teachers could have indicated this response because they were always away for meetings outside school, and so when they came back to school in the evenings, they would use prep time to sometimes advise students against the vice of drug abuse. Furthermore, head teachers provided morning assembly sessions as occasions when students were advised against the vice of drug abuse. This could be because head teachers were the ones given a lot of time during morning assembly time and so could talk as much as possible even on issues concerning shunning drug abuse.

According to teachers and head teachers, occasionally, experts were invited to advise students against this vice of drug abuse. Such experts included religious leaders and medical professionals like doctors, nurses and dentists. Teachers and head teachers said the response rate by students to these experts was very successful. Furthermore, the head teachers provided the qualities they base on when inviting these professionals who advise students against drug abuse. These qualities were the educational level of the individual which means he or she must be well-educated and informed to be invited to advise students. The individual must also have a good religious record. In this case, such individuals could be religious leaders like Imams or Shiekhs in the Muslim religion. Furthermore, the experts must also have experience or advisory record in society concerning advising youngsters against drug abuse. The individuals to be selected must also be of high discipline or integrity in society. For instance, that person should not himself or herself be abusing drugs. Sometimes also the profession of the expert was necessary and this explains why the head teachers could invite professionals from the medical field because they were well-versed with effects of drug abuse. 
Despite the fact that head teachers were aware of which qualities to base on in order to invite any particular expert to advise students against drug abuse, the invitation of such experts was not a frequent habit. The implication was that head teachers had not taken this as a serious problem in the schools.

\section{Actions Taken by School Administration towards Students who Abuse Drugs}

Students were asked to indicate the actions taken against any students found abusing drugs. Figure 3 shows students' responses on actions taken by school administration.

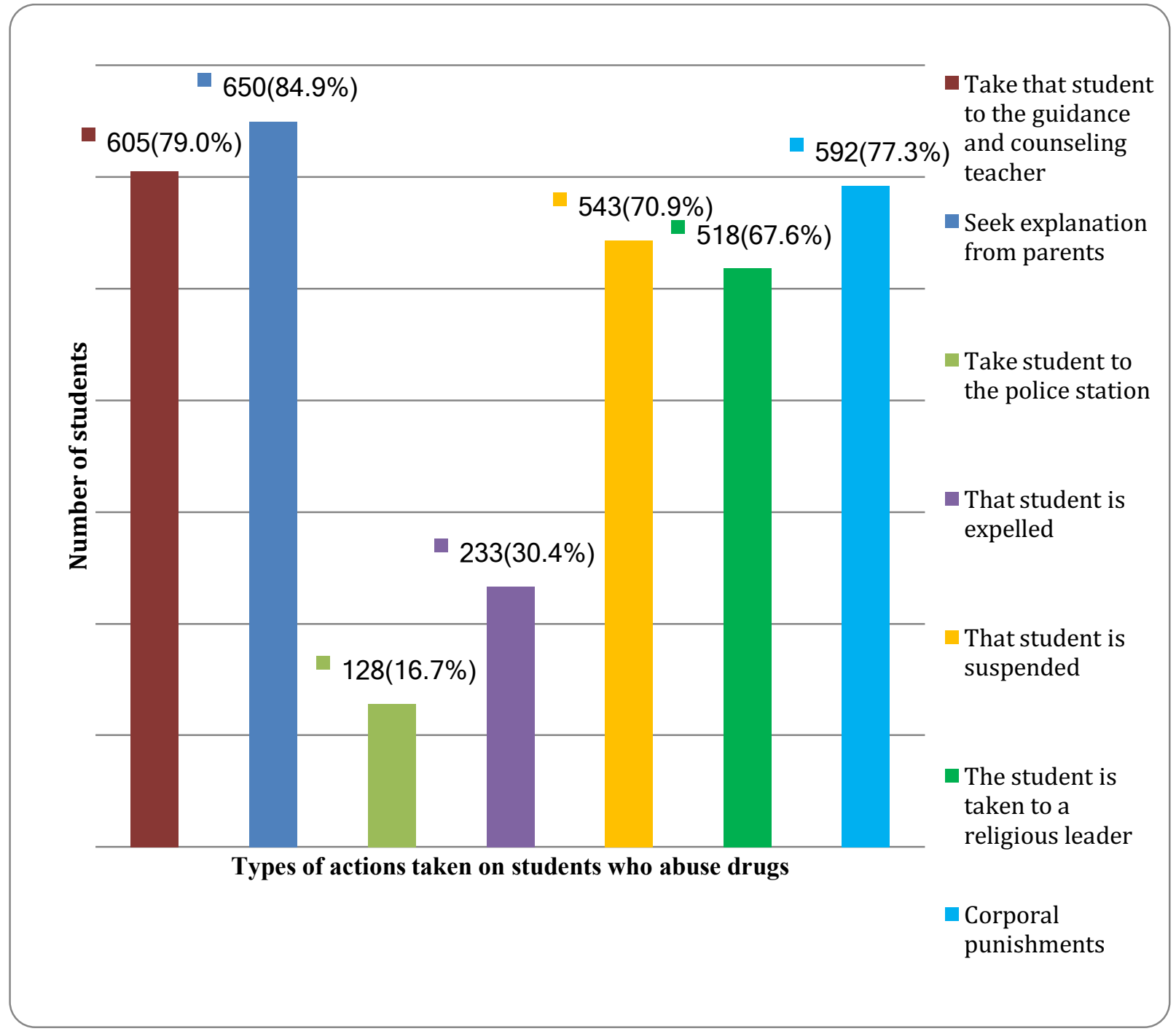

Figure 3: Students' responses on actions taken on drug abusers

Figure 3 illustrates actions taken by the school administration when a student was caught abusing drugs according to student responses. Seventy-nine per cent of the students reported that drug abusers were taken to the guidance and counselling teacher for counselling, 84.9\% reported that the school administration sought explanation from parents, $70.9 \%$ reported that the student was suspended, $67.6 \%$ reported that the student was taken to the religious leader while $77.3 \%$ cited corporal punishments. The high percentages of responses indicate that these were the major punishments taken on students caught involving in drug abuse.

The study established that the guidance and counselling teachers played an integral role in these schools. The teachers were sometimes sponsored to attend various seminars organized by NACADA and Amani Counselling Centre (which is a training institute) in Nairobi. They were also sponsored to attend seminars and workshops by local non-governmental organizations 
like 'Mikono' International, Red Cross and Action Aid. All these non-governmental organizations have headquarters in Garissa town but their areas of operation spread to cover the County. Therefore, the office of the guidance and counselling teacher plays an important role in dealing with cases of drug abuse.

Parents were also contacted in case their children were involved in drug abuse. This would be explained by the fact that drug abuse was viewed as a very serious problem in the schools and hence parents were called upon for assistance in curbing the problem. The habit which also occurred in some homes like miraa chewing, prompted parents' participation to help minimize the problem by understanding how the addiction could have started among their children. According to the study, students were also suspended and when reporting back, they were supposed to report with a parent. Suspension was meant to give the child psychological torture when out of school. The study established that students do not take these punishments seriously and often report back with different people like step-parents, uncles, elder cousins and even other distant relatives since many parents were not always at home but on the move in different places (nomadic lifestyle) to look after their livestock or doing business.

Other students also reported being taken to a religious leader (67.6\%) when found abusing drugs. Religious leaders are very important in Garissa County and are highly respected. This is due to the fact that they offer spiritual guidance and are the ones who lead people in prayers. The same applies in the school situation where students have a lot of respect for religious leaders due to their spiritual guidance and their special role in leading others during prayers. It was, therefore, hoped that the advice of spiritual leaders would be taken seriously. In Garissa County, religious leaders visit schools on several occasions to conduct prayers and even teach students on a variety of religious issues. Also, some teachers are religious leaders having titles like Shiekhs. Furthermore, there were religious student leaders chosen by Young Muslim Association in all schools who reported to the Association about the spiritual welfare of other students. Therefore, students found abusing drugs could be reported to such religious leaders.

The study also established that corporal punishments $(77.3 \%)$ were carried out in Garissa County. Such corporal punishments included caning, sweeping classrooms, watering school trees and washing school latrines. The implication was that even if corporal punishments have been banned in schools, the school administration in Garissa County still enforced them on students. This could also be explained that parents when called to school to solve an indiscipline problem of their children concerning drug abuse, they were nowhere to be found, but children coming with relatives or even other outsiders back to school. Therefore, teachers could find a shortcut of instilling corporal punishment to the student involved. Figure 4 shows teachers' responses on actions taken by school administration towards students who abuse drugs. 


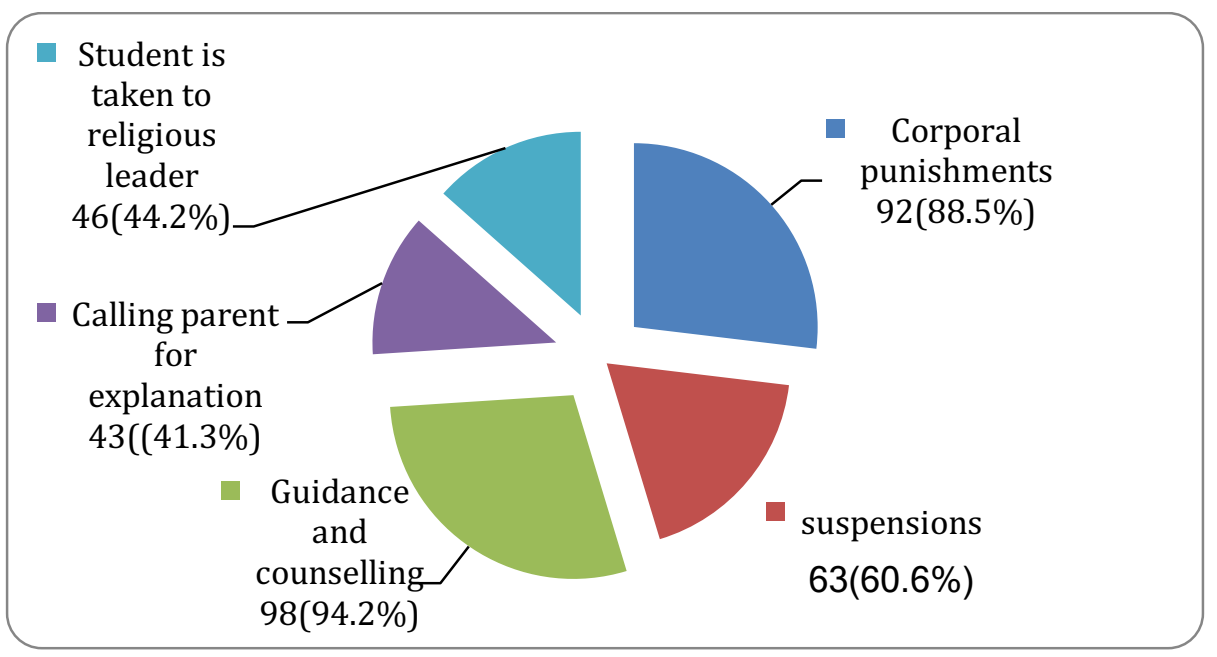

Figure 4: Teachers' responses on actions taken against students found abusing drugs

Figure 4 shows teachers' responses on actions taken against drug abusers. The findings illustrate that the main actions taken against students who abuse drugs were corporal punishments (88.5\%), suspensions (60.5\%), and guidance and counselling (94.2\%). The head teachers' responses also provided corporal punishments, suspensions and guidance and counselling as the main steps taken against students found abusing drugs. These responses show that even if corporal punishments have been banned in schools, the school administrations in Garissa County were still enforcing them. This could be interpreted that not all these schools engage in open dialogue with students as required these days when caning has been banned. These schools further, carry out suspensions mainly as the study had revealed. However, students also would like to be heard but not only to be seen (Kinyanjui, 1975). In a school where democracy is embraced, for students as well, suspensions should come as the last option in situations where a student would be caught abusing drugs.

The fact that these schools also enforce guidance and counselling among students found abusing drugs, demonstrates that guidance and counselling department was in existence in Garissa County schools in accordance with TSC (Teachers Service Commission) rules and regulations. This department is very vital in the schools today especially with the banning of corporal punishment. With the existence of the department of guidance and counselling, there was no need of enforcing corporal punishment and suspensions as the main measures of dealing with drug abuse.

The study further established that calling of parents for an explanation was also a measure taken against students found abusing drugs. This was established through the interviews from teachers as well as head teachers. This was because head teachers were the ones who had the authority of calling parents in case of any indiscipline problems. Furthermore, it was teachers who would report such cases to head teachers before the head teachers could take any action. Unlike teachers, head teachers never indicated the measure of taking the student to a religious leader. This could be because this measure was carried out, but the head teachers never mentioned it because it was not an official measure recognized by the school administration.

\section{Ways of Minimizing Drug Abuse among Students}

Students were also asked for their opinions on the most effective ways of minimizing drug abuse in their schools. Their responses are indicated in Table 2. 
Table 2: Responses on ways of minimizing drug abuse

\begin{tabular}{|c|c|c|c|c|c|c|}
\hline \multirow{2}{*}{$\begin{array}{l}\text { Ways of minimizing drug } \\
\text { and Substance abuse }\end{array}$} & \multicolumn{2}{|l|}{ Students } & \multicolumn{2}{|c|}{ Teachers } & \multicolumn{2}{|c|}{ Head teachers } \\
\hline & $\begin{array}{l}\text { Number } \\
\text { of } \\
\text { students }\end{array}$ & Percent & $\begin{array}{l}\text { Number } \\
\text { of } \\
\text { teachers }\end{array}$ & Percent & $\begin{array}{l}\text { Number } \\
\text { of } \\
\text { teachers }\end{array}$ & Percent \\
\hline $\begin{array}{l}\text { Administration being more } \\
\text { strict in enforcing school rules } \\
\text { and regulations }\end{array}$ & 218 & 28.5 & 55 & 52.9 & - & - \\
\hline $\begin{array}{l}\text { Stepping up awareness } \\
\text { campaigns in schools }\end{array}$ & 219 & 28.6 & 70 & 67.3 & 13 & 100 \\
\hline $\begin{array}{l}\text { Expelling drug users from } \\
\text { schools }\end{array}$ & 60 & 7.8 & 38 & 36.5 & - & - \\
\hline $\begin{array}{l}\text { Giving guidance and } \\
\text { counselling to students }\end{array}$ & 139 & 18.1 & 97 & 93.3 & 12 & 93.3 \\
\hline $\begin{array}{l}\text { Reducing pocket money given } \\
\text { to students }\end{array}$ & 20 & 2.6 & 29 & 27.9 & - & - \\
\hline $\begin{array}{l}\text { Introducing life skills } \\
\text { education in schools }\end{array}$ & 110 & 14.4 & 30 & 28.5 & - & - \\
\hline $\begin{array}{l}\text { The local community to help } \\
\text { the school administration in } \\
\text { minimizing the behaviour. }\end{array}$ & 62 & 59.6 & - & - & 13 & 100 \\
\hline $\begin{array}{l}\text { Control of programmes in the } \\
\text { media }\end{array}$ & 57 & 54.8 & - & - & - & - \\
\hline $\begin{array}{l}\text { Regular inspection of students' } \\
\text { dormitories and boxes for } \\
\text { drugs of abuse. }\end{array}$ & 47 & 45.2 & - & - & - & - \\
\hline $\begin{array}{l}\text { Involving parents in } \\
\text { monitoring their children. }\end{array}$ & 29 & 27.9 & - & - & - & - \\
\hline
\end{tabular}

Source: Field Data, 2017

Table 2 shows students' opinions on ways of minimizing drug abuse. The students reported that drug abuse could be minimized by the school administration being strict in enforcing school rules and regulations (28.5\%), giving frequently awareness campaign in schools $(28.6 \%)$ and giving guidance and counselling to students $(18.1 \%)$. Therefore, these were seen as the main ways of minimizing drug abuse by students in Garissa County. Such findings show that students were against the harsh measures like corporal punishment, suspensions and expulsions. Thus students also want to be talked to, be listened to and be heard (Kinyanjui, 1975).

The study shows that students were aware that the school administration should be more strict against the vice (28.5\%) so that it could be minimized. Among the areas that illustrate the lax school administration in Garissa County were the evident broken down school fencing which made it possible for students to move in and out of school through illegal outlets ( so called 'panya' routes) during odd hours like night time. Furthermore, many schools allow students to go out of compound very often especially Fridays when they are allowed to go for midday prayers to worship in mosques of their choice. Also, the frequent water shortage in schools makes it necessary for the school administration to allow students to go out of school to get water for their daily use. It seems that the school administration has not put it as a priority to confine students within the school compound. 
Strengthening the department of guidance and counselling (18.1\%) was also seen as a way to minimizing the problem of drug abuse. It seems many students were not comfortable with the existing preventive measures like corporal punishment. Such punishments inflicted pain and discomfort on students. Students also preferred preventive measures that did not belittle them. Corporal punishments like caning usually were submissive and tended to belittle the students. The students also need measures that require their reason and that value their dignity as also human beings. The students who were already addicted especially also needed effective guidance and counseling. This study has shown that there were many students who were addicted and this was one of the reasons why there was continuity of the vice of drug abuse.

Stepping up the awareness campaigns in schools about dangers of drug abuse was cited by students (28.6\%) as another major measure of minimizing drug abuse in schools of Garissa County. The study had established that the drug education given to students in secondary schools in Garissa County was not satisfactory. Furthermore, 51.7\% of the students also agreed that there were no enough seminars, meetings, and workshops that teach against the habit of abusing drugs. These findings illustrate that a lot needs to be done to enlighten students against the habit of abusing drugs so that they would willingly abstain from the habit.

Though some non-governmental organizations like `Mikono International', Action Aid, and Red Cross, have done a little in Garissa County, this drug education could not be judged as satisfactory. The drug awareness campaign supposed to be done by NACADA is evidently wanting. NACADA has no established office in Garissa County and yet it is a parastatal responsible for creating drug awareness campaigns among the youth especially in Kenyan schools. Even if NACADA has sometimes held workshops in Garissa County, but the number of times it has done this is very few. NACADA has tended to concentrate in other areas like Nairobi and Mombasa leaving this problem of drug abuse to grow up and increase in other areas like Garissa County.

According to teachers' interview responses in table 2 above, the main ways of minimizing drug abuse were strengthening the department of guidance and counselling (93.3\%), educating students on the dangers of abusing drugs $(67.3 \%)$, controlling programmes in the media (54.8\%), the local community to help the school administration in minimizing the behaviour of drug abuse (59.6\%), and also school administration being more strict in enforcing school rules and regulation (52.9\%). Therefore, these were the main ways of minimizing drug abuse according to teachers. According to these findings, teachers and head teachers were not totally in agreement on the various effective ways of minimizing drug abuse.

Strengthening the department of guidance and counselling (93.3\%) was seen as a major measure that could be used to minimize drug abuse by students, teachers as well as head teachers. This could be interpreted that guidance and counselling department in schools in Garissa County were not very effective. Students could be aware of this shortcoming since their personal problems had not been fully solved by these departments. They could also be seeing some of their school-mates abusing drugs and yet these departments had not come in to counsel them fully so that they could avoid the habit. Teachers as well could be aware of the weakness of this department in schools in Garissa County. Teachers could be aware that they were not frequently sponsored to go and attend training organized by national bodies like NACADA and Amani Training Centre in Nairobi or even locally by non-governmental organizations like 'Mikono' International, Action Aid and Red Cross. Furthermore, head teachers could also be aware that this department was not serving students as required. This could be because head teachers knew the schools in Garisaa and Ijara did not have enough funds to sponsor teachers to attend workshops and seminars orgainized by NACADA and 
Amani Training Centre in Nairobi. Furthermore, these schools did not have enough funds to organize for local training of teachers in guidance and counselling. Various studies which have also advocated for guidance and counseling include Arudo (2008) and Ngesu (2008).

The teachers also indicated controlling programmes in the media (54.8\%) as a measure to minimize drug abuse in schools. This measure was never mentioned by head teachers nor students themselves. Students like watching television sets where all sorts of social drugs were advertised in a very appealing way (Kombo, 2004). Students would then imitate what goes on in the television sets and start abusing drugs. Some teachers being parents could be aware of this problem and how it makes many youngsters turn to drug abuse.

The school administration being more strict (52.9\%) was mentioned by students as well as teachers. However, the head teachers never cited this as an effective measure to minimize drug abuse. The students would have been aware that the school administration was not very strict since drug abuse was continuing in their schools and yet the school administration has not done much to minimize it. Teachers also could notice drug abuse problem going on and yet the school administration did nothing to minimize it. Furthermore, teachers do not have enough powers to summon parents but it was the head teachers who had overall powers. The fact that head teachers did not mention the school administration being more strict simply implies that they were acting defensive to protect their names as administrators.

The school community to help school administration in minimizing drug abuse (59.6 \%) was cited as the main way of minimizing drug abuse by teachers. Similarly, head teachers cited this measure. This was because in Garissa County, drugs like miraa and cigarettes were openly abused by community adult members. This were poor role models for students. Since the community abused such drugs openly, it would be very hard to report students found abusing the drugs to the school administration as the community was as well involved. Furthermore, selling of these drugs like miraa and cigarettes was considered an income generating activity by the community members as through this most of them earned their living.

Drug education was mentioned as a major way of minimizing drug abuse by teachers (67.3\%) as well as head teachers. Teachers and head teachers could be aware that students were not being fully enlightened about the effects of drug abuse because they were the ones charged with the welfare and education responsibility of students in schools and could therefore, know the depth of drug education offered. This measure is very important since students would willingly avoid abusing drugs. Students would be enlightened about the dangers of drug abuse and to avoid the habit due to the life-long repercussions of the vice. Various studies in developed and developing countries advocating for this method of minimizing drug abuse include studies by Blue Cross Namibia (2008), DARE, (2017); Kombo, (2004); Maithya, (2009); Mugagga, (2010); NDLEA, (2009); Nyambe, (1979); Parry, (1998); NDAP, (2004); and FCD Educational Services, (2009).

\section{CONCLUSION}

Based on the study findings established in the paper, the menace of drug abuse among secondary school students in Garissa County is widespread and spells danger not only for the students abusing the drugs, but also for the wellbeing of schools and the country at large. The study established that a variety of drugs are abused by students in the schools the most common being miraa cigarettes, bhang and alcohol among other narcotic drugs. It was established that most of these drugs are easily available or locally produced allowing the students easy access. The study also determined the measures put in place to curb the menace drug abuse in the schools. Some of measures include: summoning parents or guardians to 
school, guidance and counselling, suspension, talks during assembly, expulsion and impromptu inspections.

\section{RECOMMENDATIONS}

- The Ministry of Education should mount intensive training for all school counselors to give them relevant skills and approaches in handling student drug abusers.

- The issue of drug abuse among the students should be made a top most agenda for policy makers in the country, especially elected leaders and religious leaders to maintain long-term commitment to solving the drug menace.

- Awareness on drug abuse repercussions should be intensified through advocating for and meet-the-people in campaigns

- Since some parents may lack exposure on issues relating to drug abuse, the Ministry of Education and NACADA should take the lead in organizing parenting programmes on how to address drug abuse among their children.

\section{References}

Arudo, T.0.0. (2008). Peer Counseling Experience among Selected Kenyan Secondary Schools. (Unpublished Thesis), Kenyatta University.

Blue Cross Namibia (2008). Prevention in Windhoek's Schools. Windhoek. International Blue Cross.

CASA (2017). The Effects of Drug Abuse on Teens. Del Mar, California. Casa Palmira Treatment Center, USA.

CASA (2017). Malignant Neglect: Substance Abuse and America's schools. Columbia University, USA.

City Education Department (1979). A Handbook for Primary School Head teachers in Kenya. Nairobi: Longman Ltd.

DARE UK (2017). DARE In The United Kingdom. London: Wikimedia Foundation.

DARE US (2017). Drug Abuse Resistance Education. California: Wikimedia Foundation.

FCD (2009). About Freedom from Chemical dependants. Massachusetts: FCD Educational services.

Kenya Safaris Guide (2011). Kenya Rehabilitation Centers, Therapy, Recovery, Treatment. Nairobi. Kenya Safaris Guide.

Kiiru, D. (2004). Youth in Peril: Alcohol and Drug Abuse in Kenya. Nairobi: NACADA.

Kinyanjui, K. (1975). Secondary school strikes: The Art of Blaming the victim. IDS. University of Nairobi.

Kombo, D. K. (2004).The Impact of Drug Abuse Sensitization Campaigns in Kenya. Cited from Status of Environmental Health Education in the East Africa Region: Opportunities, Challenges and the Way forward. Department of Environmental Health. Kenyatta University.

Kombo, D.K. (2005). Sociology of Education. Nairobi: Adprint Publishers.

Maithya, R.W. (2009). Drug Abuse in Secondary Schools in Kenya: developing a Programme for Prevention and Intervention. (Unpublished Thesis), University of South Africa.

Milliken, A. (2017). Alcohol and drug education in schools. Published by Mentor- Adepis . London, UK.

Mugagga, R. (2010). Cocaine, Heroin, no Rampant Schools. Kampala. (Uganda youth Development Link (UYDL).

NDAP (2004a) Specialist Manual. Los Angeles: CA Narconon International.

NDAP (2004b) Drug Abuse Prevention Program Description. California. Narconon Drug abuse Prevention Program.

NDLEA (2009). NDLEA strategies. Lagos. Drug Demand Reduction Unit.

Ngesu, J. M., Ndiku, J., Magese, J. (2008). Drug Dependence and Abuse in Kenyan Secondary Schools: Strategies for Intervention. Educational Research and Review 3(10). University of Nairobi, Kenya, Masinde Muliro University.

NIDA (2015).Statistics Regarding Substance Abuse and Chemical Dependence. Washington D.C.: National Institute of Health. 
Nyambe, B., (1979). United Nations Educational Scientific and cultural organization in Education concerning problems associated with the use of drugs in Zambia, Kenya, and Switzerland from point of view of W.H.O. UNESCO and Inter pool. Lusaka: UNESCO.

Parry, C.D.H. (1998). Substance Abuse in South Africa: Country Report focusing on Young Persons. Mental Health \& Substance Abuse, Medical Research Council, Tygerberg, South Africa. .

Shurgin, A.H. (2011). Culture of Somalia- history, people, women, beliefs, food, and customs. United Nations Development Programme Somalia. 